\title{
Effect of Different Angle Scanning on Density Estimation Based on Hounsfield Unit on CT and CBCT
}

(Kesan Imbasan Sudut Berlainan ke atas Anggaran Kepadatan berdasarkan Unit Hounsfield pada CT dan CBCT)

\author{
Maya GenisA*, Zainul Ahmad RaJion, DasmaWATi Mohamad, AbDUllah PoHChi, \\ MOHD RAFIQ ABDUL KADIR \& SOLEHUDDIN SHUIB
}

\begin{abstract}
This study aim to evaluate the effect of different angle on bone density estimation based on HU on CT and CBCT scanning. A phantom of jaw was scanned using CT and CBCT machine from different angle (0,15 and 30 degrees). The data were transformed into DICOM format and loaded into MIMICS software for density measurement. The density was measured at $9.55 \mathrm{~mm}$ from cemento-enamel junction (CEJ) on every different angle scanning data. Then these data were grouped as Group A1, A2 and A3 for CBCT group (0, 15 and 30 degrees, respectively) and Group B1, B2 and B3 for CT group (0, 15 and 30 degrees, respectively). The differences between the groups and the references (0 degree scanning) are measured statistically using SPSS software. In the CBCT data, the density reading at 15 and 30 degrees are higher than 0 degree scanning (mean difference $=-155.63 \pm 62.61, \mathrm{p}=0.03$, mean difference $=-33.13 \pm 84.24, \mathrm{p}=0.206$ for 15 and 30 degrees scanning, respectively). In the CT data, the density at 15 and 30 degrees scanning is lower than at 0 degrees scanning (mean different: $84.49 \pm 46.76, \mathrm{p}=0.09$ and 15.09 $\pm 23.61, \mathrm{p}=0.532$ ). The differences are not significant statistically. Compared with CT, the effect of different angle scanning on density estimation on CBCT is stronger. These results showed that different angle scanning produce more error on density estimation based on HU on CBCT compared with CT. This study demonstrated that the uses of a CBCT and CT for density monitoring to evaluate bone density of jaws are affected by angle scanning.
\end{abstract}

Keywords: Angle scanning; cemento-enamel junction; density; Hounsfield unit

\section{ABSTRAK}

Matlamat kajian ini adalah untuk menilai kesan sudut berbeza pada anggaran ketumpatan tulang berdasarkan HU pada imbasan CT dan CBCT. Model rahang telah diimbas dengan menggunakan CT dan CBCT daripada sudut berbeza $(0,15$ dan 30 darjah). Data diubah kepada format DICOM dan dimuatnaik ke dalam perisian MIMICS untuk pengiraan ketumpatan. Ketumpatan diukur pada $9.55 \mathrm{~mm}$ dari temuan simento-enamel (CEJ) di setiap sudut berbeza data imbasan. Data ini kemudiannya dikumpulkan sebagai Kumpulan A1, A2 dan A3 untuk kumpulan CBCT (masing-masing 0, 15 dan 30 darjah) dan Kumpulan B1, B2 dan B3 bagi kumpulan CT (masing-masing 0, 15 dan 30 darjah). Perbezaan antara kumpulan dan rujukan (O darjah imbasan) diukur secara statistik menggunakan perisian SPSS. Dalam data CBCT, bacaan ketumpatan pada 15 dan 30 darjah adalah lebih tinggi daripada 0 darjah imbasan ( min beza $=-155,63 \pm 62.61, \mathrm{p}=0.03$, min beza $=$ $-133,13 \pm 84.24, \mathrm{p}=0,206$ pada 15 dan 30 darjah imbasan). Dalam data CT, ketumpatan pada 15 dan 30 darjah imbasan

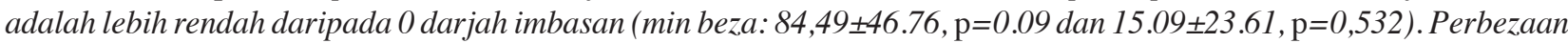
ini tidak ketara secara statistik. Berbanding dengan CT, kesan imbasan sudut berbeza pada anggaran kepadatan CBCT adalah lebih kuat. Keputusan ini menunjukkan bahawa imbasan sudut berbeza menghasilkan lebih banyak ralat dalam anggaran kepadatan berdasarkan HU pada CBCT berbanding CT. Kajian ini menunjukkan bahawa penggunaan CBCT dan CT untuk memantau ketumpatan dalam menilai ketumpatan tulang rahang dipengaruhi oleh imbasan sudut.

Kata kunci: Ketumpatan; sudut imbasan; temuan simento-enamel; unit Hounsfield

\section{INTRODUCTION}

Bone quality and quantity of jaw is an important factor that could determine the success of dental implant. Not only for pre-implant evaluation, bone density assessment can also be performed post implant to evaluate osseointegration process. The clinical studies showed that there is high correlation between bone quality and quantity and survival of implant such as the greater implant survival in the mandible than in the upper maxilla, due to the area's characteristics (Farré-pagès et al. 2011).

Time lapse monitoring on bone quality and quantity post implant is performed regularly to evaluate the osseointegration of post implant placement. At least there are two common methods to evaluate bone density through image evaluation; CT and CBCT scanning. This paper investigated the effect of different angle during scanning 
on density estimation based on Hounsfield value on both of these methods.

Conventional CT scanning have been applied for evaluation of bone density of jaw as reported by Turkyilmaz and Mcglumphy (2008). In their investigation, 111 of patients with 300 implants were scanned using CT. They showed that the local bone density has a prevailing influence on primary implant stability. Similarly, Yunus (2011) in his study involved 30 patients who had lost 1 posterior tooth in the maxilla or mandible and installed the dental implant. The patients has been scanned using CT before and after implant placement. Hounsfield Unit (HU) was used to evaluate the difference of bone density before and after implant installation, their result showed that bone density around dental implant was increased after implant placement.

The application of Conventional CT for dental imaging is common because of its resolution as reported by Gulsahi (2009), he used conventional CT through the panoramic image to describe the anatomy of the jawbone in two dimensions precisely. However, the conventional CT use high doses of x-ray (Benson et al. 1991) the panoramic mandibular index (PMI; Chan et al. 2010), hence the application of other scanning method which has low doses of X-ray such as the cone beam computer tomography $(\mathrm{CBCT})$ is favoured for monitoring purposes.

Recently, due to dose of $\mathrm{x}$-ray issues, СBCT technique is more popular to be used as tools to evaluate the site implant (Alamri et al. 2012). High resolution, low radiation dose and lower costs compared with $\mathrm{CT}$ are the advantages of CBCT method. Some workers have applied CBCT scanning into dental implant technology to estimate bone quality and quantity (Hsu et al. 2011; Isoda et al. 2012) which represented a quantitative unit called the implant stability quotient (ISQ; Kaya et al.2012; ). They evaluated the bone quality and quantity based on HU of CBCT data.

Shapurian et al. (2006) used the index of Hounsfield Unit (HU) from CT and СBCT data to estimate bone density quantitatively. However, HU either on CT or CBCT are sensitive with distance or position of the object from the source (Swennen \& Schutyser 2006). Ali and Ahmad (2009) investigated the sagging shift effect on СВСТ data. They reported that value of $\mathrm{CBCT}$ data was changed about 1 to $3.5 \%$ due to sagging shift. If the position between source, object and detector are not aligned correctly, the scanning of СВСТ will produce an artefact that is called as misalignment artefacts. If there is movement of the object during scanning process, the reconstruction of image on СВCT will affect the back projection process hence the quality and value of СВCT will change (Schulze et al. 2011).

For monitoring purposes, CBCT scanning are common used especially for dental imaging. However, sometimes the exact position during repeating scanning is not achieved. Hence the effects of this dispositioning on CBCT reading need to be tested. It is interesting to investigate the effect of different angle scanning on HU reading, either on CT or СBCT data. The reliability and repeatability test both of these scanning methods for time laps monitoring purposes is needed to be performed.

\section{MATERIALS AND METHODS}

In order to evaluate the effect of different angle on bone density estimation based on Hounsfield Unit (HU) values of anatomical specimens areas, at the same spatial coordinates, a jaw phantom was scanned with three different angles; 0, 15 and 30 degrees using СТ and СВCT machine. This method allowed us to obtain the comparable images of the same region of interest.

The protocol used in this in vitro study consisted of an integrated sequence that involved several steps as shown in the flowchart in appendix. A phantom of the jaw (CIRS, $711 \mathrm{H}-\mathrm{N}$ model) was scanned using CT and СBCT machine. The scanning was performed three time for each machine, CT (Scan Siemens Definition AS+128 slices, Germany) and СВCт (Promax 3-D, Planmeca, Finland) using three different angle scanning ( 0,15 and 30 degrees). The dose for CT machine were $80 \mathrm{KV}, 302.94 \mathrm{mAs}, 0.549 \mathrm{~mm}$ voxel resolution and FOV $28.10 \mathrm{~cm}$, meanwhile CBCT machine was set to $84 \mathrm{kVp}, 168.7 \mathrm{mAs}, 0.32 \mathrm{~mm}$ voxel resolution and FOV $8 \mathrm{~cm}$.

By keeping the same configuration of the source for every different scanning, we assumed that the recorded HU on the instrument is due to the different path of the x-ray during propagation in the medium. Hence the different reading of $\mathrm{HU}$ is assumed can be correlated directly with different angle. During the density measurement using MIMICS software, the location for every point measurement was assumed fix, however, this location might produce some error. The errors due to disposition during measurement were assumed not affecting the result. These errors are compensated by choosing the area of measurement maintained constant.

Analysis and processing of those data was performed using MIMICS and Matlab software. Bone density measurement from CBCT and CT data were performed using density measurement tools in the MIMICS software with the circle area around $1 \mathrm{~mm}^{2}$. The density is measured as mean value of Hounsfield Unit (HU) per $\mathrm{mm}^{3}$. The measurements are performed in 16 locations at $9.5 \mathrm{~mm}$ from cementoenamel junction (CEJ) level.

For the statistical analysis purposes, the tabulated data were grouped into six groups which are representing the angle scanning and kind of scanning. All of those groups name are; Group A1 (0 degree), Group A2 (15 degree) and Group A3 (30 degree) for CBCT data and Group B1 (0 degree), Group B2 (15 degree) and Group B3 (30 degree) for CT data. Summary of the scanning using CBCT and CT scanning result for different angle are shown in Figures $1-4$.

\section{STATISTICAL ANALYSIS}

The tabulated data for each group were analysed using SPSS ${ }^{\circledR}$ software (Statistical Package for Social Science, Inc., Chicago, IL, USA). Descriptive statistics consisting of mean values and standard deviation were calculated for the measured Hounsfield value. T-test was used to determine 


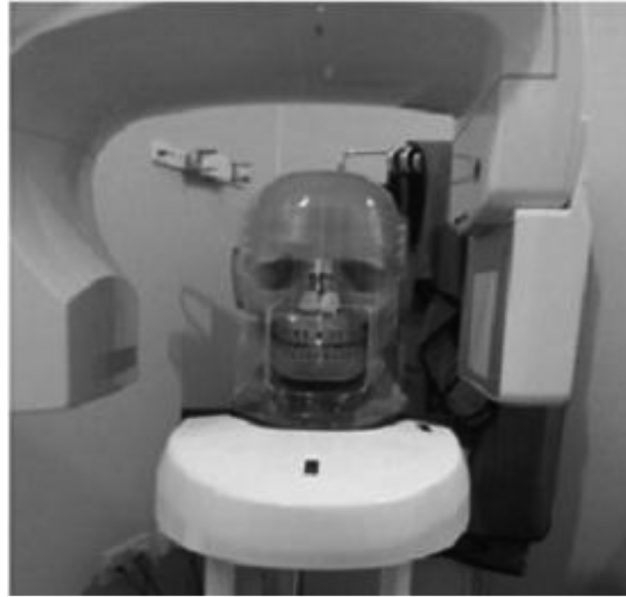

(a)

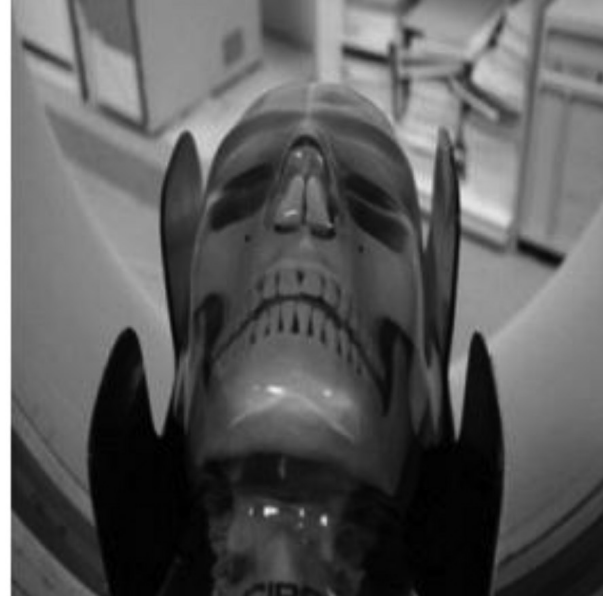

(b)

FIGURE 1. Scanning of the phantom using CBCT (a) and CT machine (b)
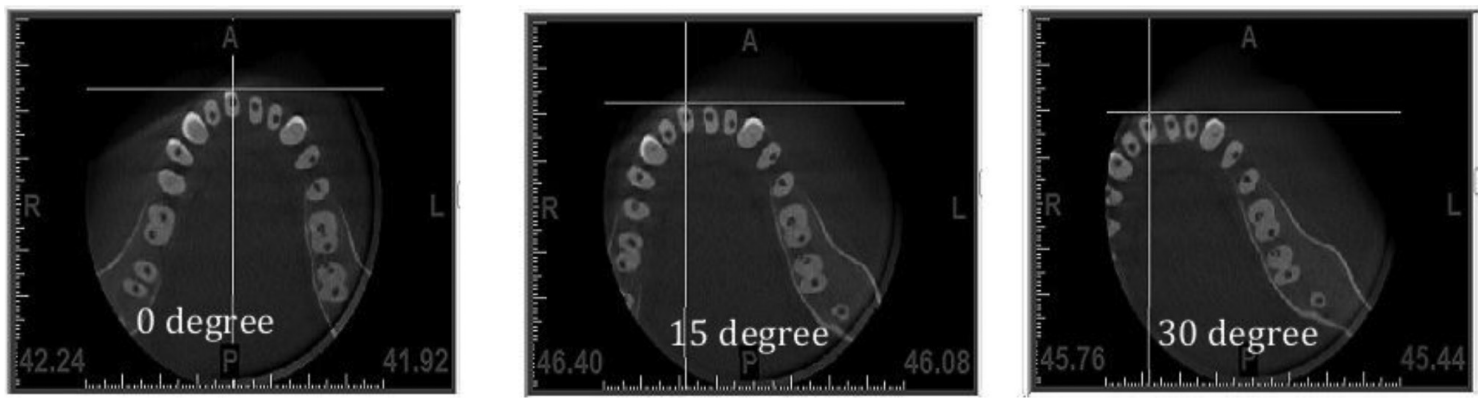

FIGURE 2. Axial view of mandible from CBCT using 0, 15, 30 degrees angle scanning
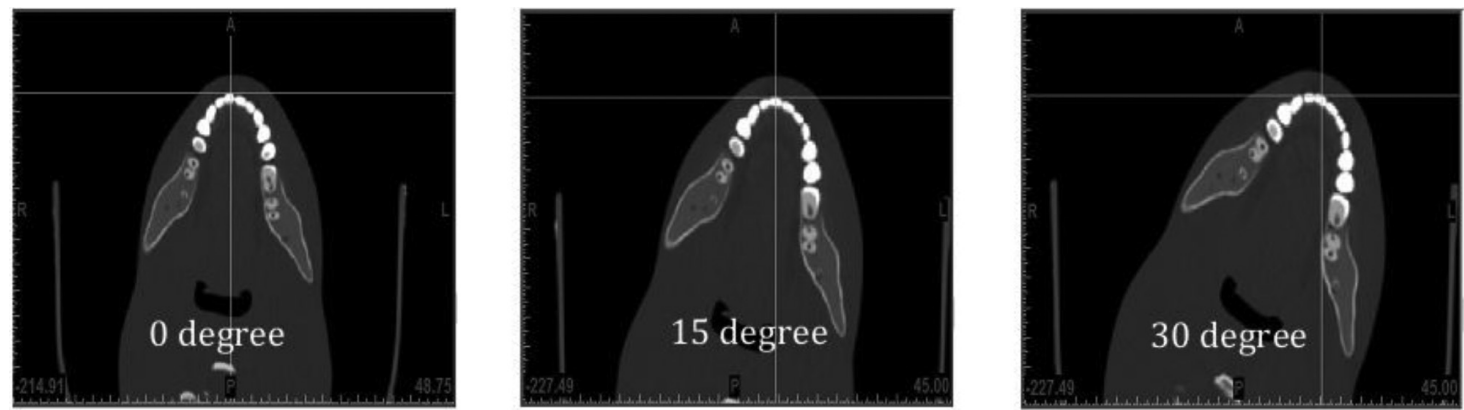

FIGURE 3. Axial view of mandible from CT using 0, 15, 30 degrees angle scanning
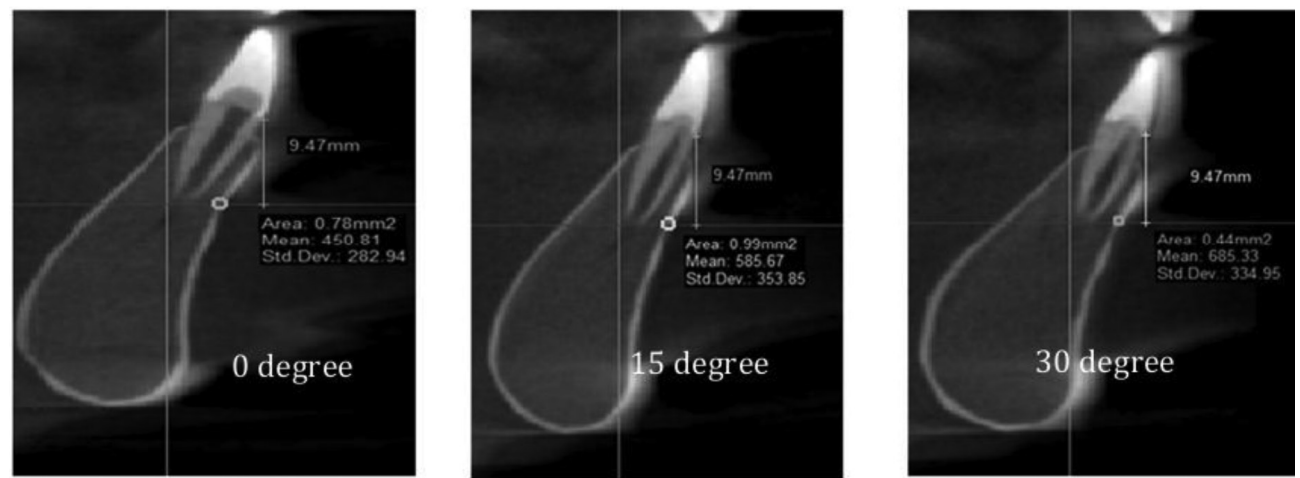

FIGURE 4 . The position of density measurement at different angles $(0,15,30$ degrees $)$ 
the significant difference among the HU of different Groups. The confidence level was set to $95 \%$.

\section{RESULT}

Quantitative data of each group was described with mean values and standard deviation (Table I). The differences of the gray density values, between the CBCT and CT groups were calculated using t-test; the results are described in the Table 2 (Group A1 vs B1, Group A2 vs B2, GroupA3 vs B3).

\section{DISCUSSION}

Since the phantom has homogeneous density, the different $\mathrm{HU}$ reading directly representing the reading error on $\mathrm{HU}$. In the same coordinate spatial, the density of phantom which is represented by HU was different in different angle scanning either on CBCT or CT. The HU readings at mandible slicing are visualized in the colour height as shown in Figures 5-8 (for СВCT) and Figures 9 and 10 (for CT). From these figure, it is clear that different angle scanning on CBCT give more errors on $\mathrm{HU}$ reading than $\mathrm{CT}$. In $\mathrm{CT}$, scanning with 0,15 and 30 degrees look like not too much different compared with CBCT. The difference value of HU did not follow the increasing in angle scanning, which tell us that the error due to different angle scanning is not linear with angle scanning, there is an error due to difference distance or position of the object to the position of x-ray source.

СBCT and CT have different acquisition configuration. The basic difference is СВCT use a cone beam source while the CT uses a fan beam source. The different type of source affect the error, due to misalignment during scanning. In the CT scanner configuration, for examples, the object is located at point $\mathbf{A}$ in the first scanning (Figure 11(a)). If this object is scanned again with $\mathrm{CT}$, the object underwent the rotation with different angle $\theta$ without translation, hence the object at position $\mathbf{A}$ (in the first scanning) will be translated into new position at $\mathbf{A}^{\prime}$ (in the second scanning). The different distance from the object to the source between these scanning is $\mathbf{r} \times \boldsymbol{\theta}$. Not only the HU are captured in the detector, this difference path will also affect the shape of projection.

Unlike the CT scanning, the different angle scanning on CBCT is more complex because of the source type of СBCT is a cone beam (Figure 11(b)). In CBCT, the rotation of object will produce the error in all direction including $\mathrm{x}$ and $\mathrm{y}$ position. This different angle on CBCT will at least trigger

TABLE 1. Statistics description of mean, standard deviation and minimum-maximum of bone density values, defined as gray density values (VV)

\begin{tabular}{ccccc}
\hline Group & Mean & Maximum & Minimum & SD \\
\hline A1 & 720.27 & 1160.78 & 298.89 & 276.40 \\
A2 & 875.90 & 1525.22 & 487 & 312.62 \\
A3 & 833.40 & 1293.91 & 557.11 & 230.94 \\
B1 & 1086.29 & 1483.44 & 698.44 & 187.63 \\
B2 & 1001.80 & 1309.78 & 609.67 & 175.50 \\
B3 & 1071.19 & 1379.89 & 652.33 & 178.83 \\
\hline
\end{tabular}

TABLE 2. T-test regarding the differences between the Groups

\begin{tabular}{cccc}
\hline Group & Significant & Difference between means & Standard error \\
\hline A1 - A2 & $0.030 *$ & 155.63 & 45.81 \\
A1 - A3 & 0.206 & 113.13 & 45.39 \\
B1 - B2 & 0.091 & 84.49 & 85.02 \\
B1 - B3 & 0.532 & 15.09 & 73.23 \\
\hline *Statistically significant $(p \leq 0.05)$ & &
\end{tabular}

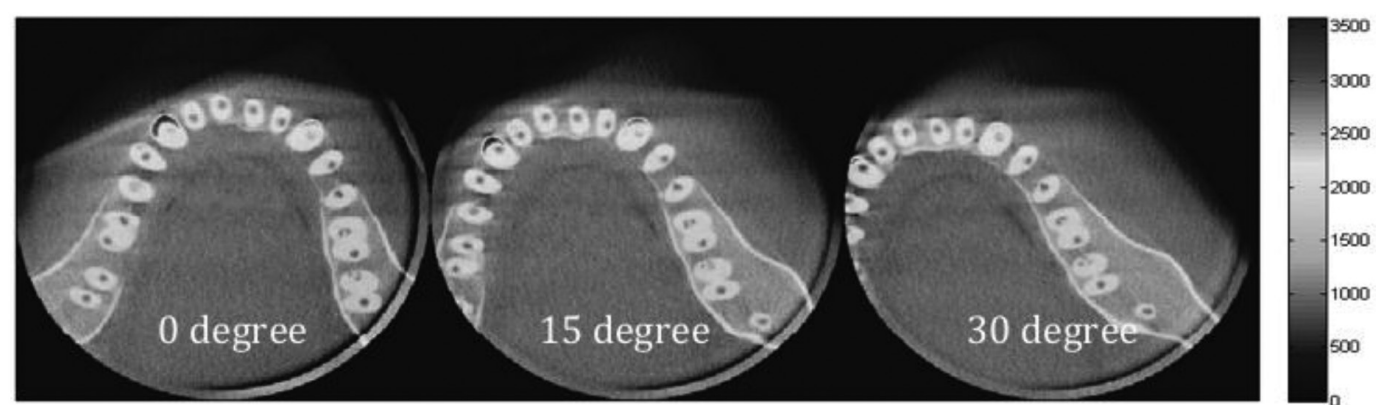

FIGURE 5. Color code of $\mathrm{HU}$ of 0,15 and 30 degrees on axial slicing CBCT data 


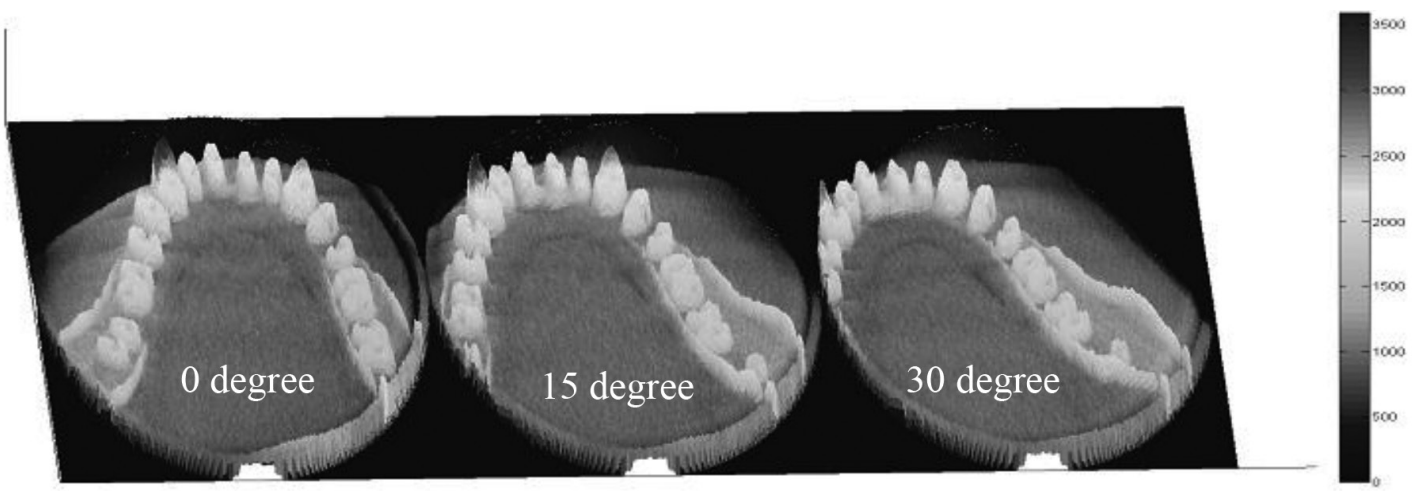

FIGURE 6. HU topography on Mandible slicing for 0,15 and 30 degrees scanning of CBCT data

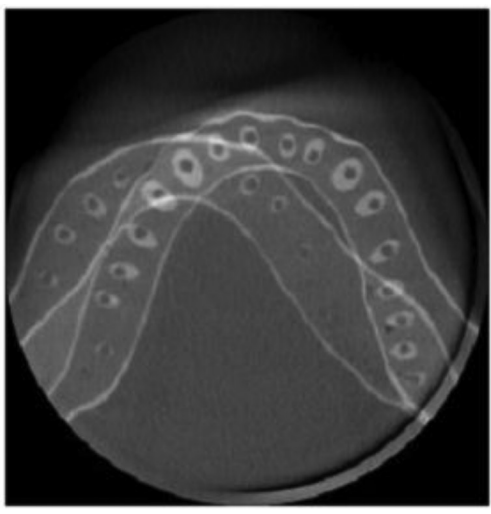

(a)

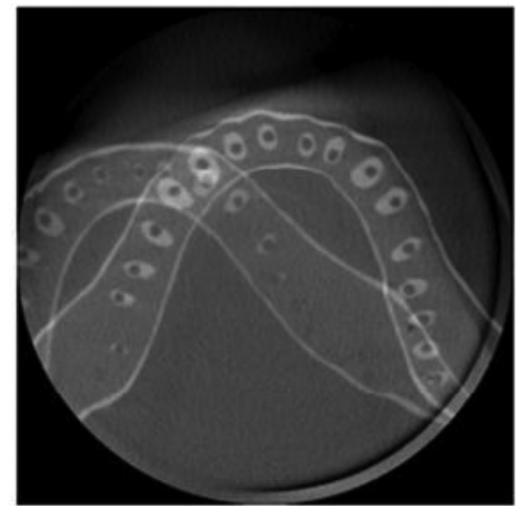

(b)

FIGURE 7. Overlap slice between 0 and 15 degrees scanning (a) and between 0 and 30 degrees of CBCT data (b)

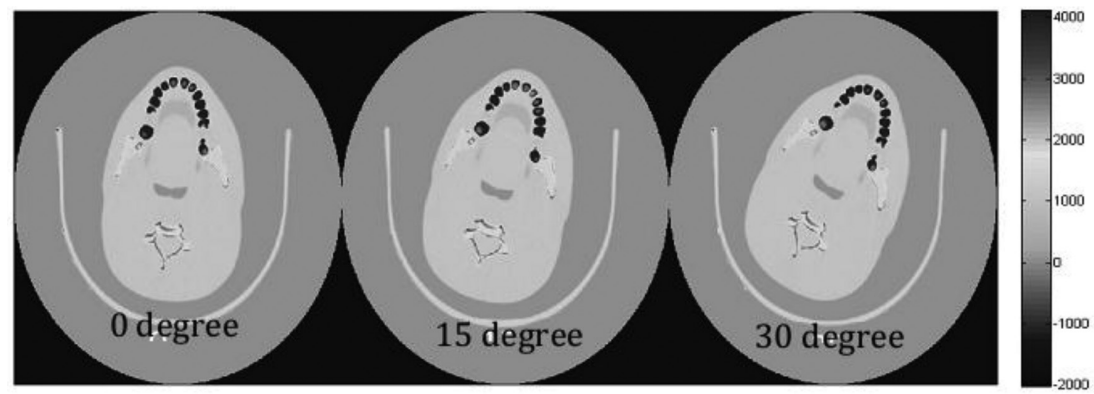

FIGURE 8. Density in term of HU in color code of 0,15 and 30 degrees CBCT data

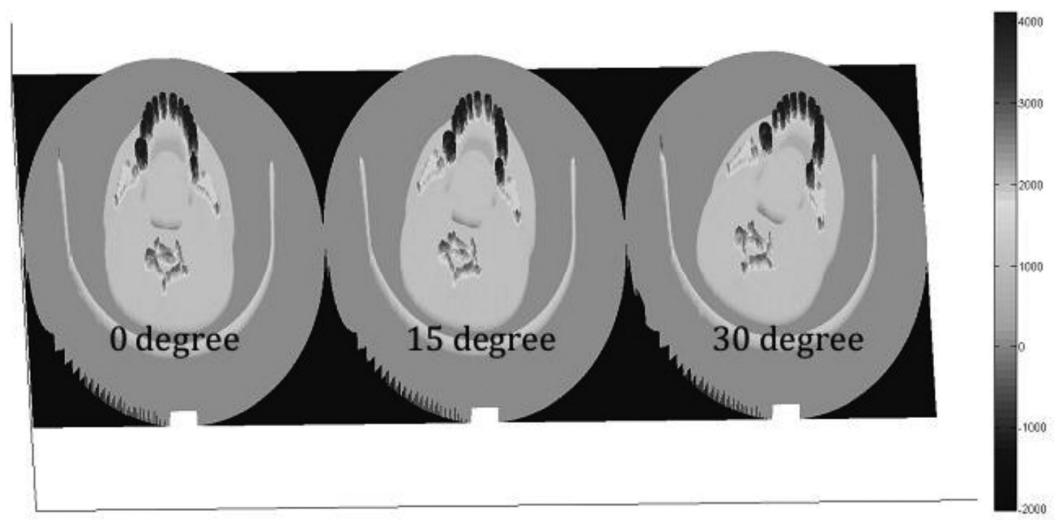

FIGURE 9. Density in term of HU in topography view of 0,15 and 30 degrees CT data 


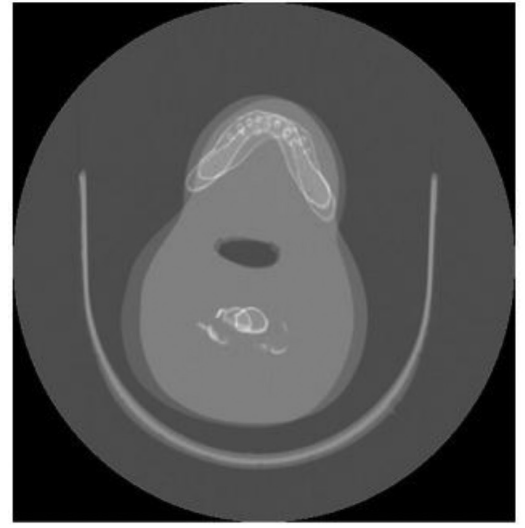

(a)

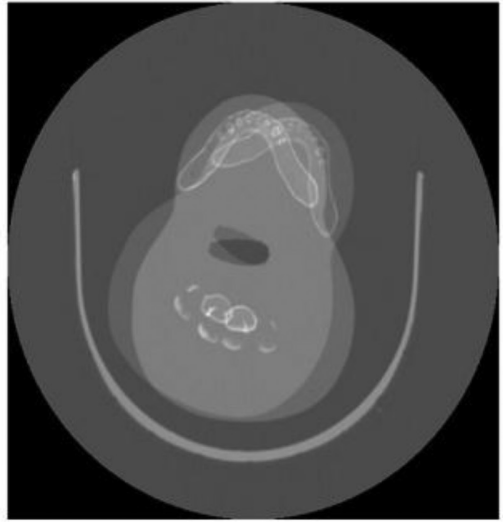

(b)

FIGURE 10. Overlapping of CT data between 0 and 15 degrees (a) and between 15 and 30 degrees (b)

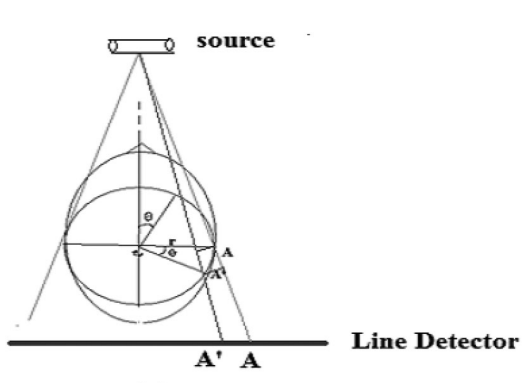

(a)

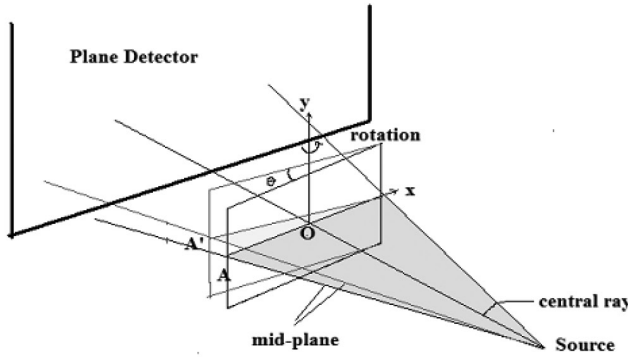

(b)

FIGURE 11. Ilustration of CT (a) and СBCT (b) scanning technique

the error in the vertical shift, horizontal- transversal shift from the central ray and horizontal-longitudinal shift along the central ray direction (Sun et al. 2006). These three deviations can produce not only the reading of $\mathrm{HU}$ projection on the plane detector but also will cause the error of shape reconstruction. In this case, $\mathrm{x}$-ray will be scattered more than in the CT configuration hence the artefact on СBCT is more than in the CT.

The error due to geometry of scanning either on CT or CBCT have been tried to be compensated. Sun et al. (2006), suggested that this error should be reduced before the image reconstruction. Not only it affect the $\mathrm{HU}$, the different angle scanning also affect the shape of image projection as reported by Ford et al. (2011). In our investigation, the result showed that the $\mathrm{HU}$ in $\mathrm{CBCT}$

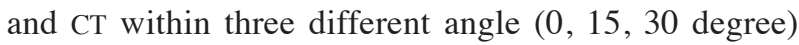
scanning produce the error in HU reading, however there are no comparable reports in the literatures.

CBCT scanning is a technique widely used in oral and maxillofacial surgery and bone density determination. The information about bone density is an important parameter in surgical planning especially in implantology. On the basis of the present study, it resulted as an accurate determination of bone density using СBCT requires a better future assessment of the limitations of the use of СBCT.
Correction due to different angle scanning should be compensated to reduce the error especially for monitoring the bone density purposes.

\section{CONCLUSION}

Based on the result, we conclude that on the in vitro study, the different angle scanning contribute to HU reading either on CT or CBCT scanning. As consequences, the diagnostic which is based on monitoring of СBCT or CT reading should be taken carefully. The misalignment due to disposition during scanning should be avoided to minimize the effect of different angle on HU estimation. This effect technically also possible to be compensated during the reconstruction image on the back propagation stage to gaining the reliability and repeatability of $\mathrm{CBCT}$ or CT scanning for monitoring purposes. Measurements of this effect on the density of in vivo still need further investigation.

\section{ACKNOWLEDGEMENTS}

We would like to thank Mohd. Firdaus, Nur Syafini, Noor Fataha and Johari Yap Abdullah from the Department of Radiology, Hospital Universiti Sains Malaysia for their technical support. 


\section{REFERENCES}

Alamri, H.M., Sadrameli, M., Alshalhoob, M.A., Sadrameli, M. \& Alshehri, M.A. 2012. Applications of CBCT in dental practice : A review of the literature applications in oral and maxillofacial surgery. General Dentistry 60(5): 390-400.

Ali, I. \& Ahmad, S. 2009. Evaluation of the effects of sagging shifts on isocenter accuracy and image quality of cone-beam CT from kV on-board imagers. Journal of Applied Clinical Medical Physics 10(3): 180-194.

Benson, B.W., Prihoda, T.J. \& Glass, B.J. 1991. Variations in adult cortical bone mass as measured by a panoramic mandibular index. Oral Surgery, Oral Medication, Oral Pathology 71(3): 349-356.

Chan, H., Misch, K. \& Wang, H. 2010. Dental imaging in implant treatment planning. Implant Dentistry 19(4): 288-298.

Farré-pagès, N.M.,Augé-castro, L., Alaejos-algarra, F., Marequebueno, J., Ferrés-Padró, E. \& Hernández-Alfaro, F. 2011. Relation between bone density and primary implant stability. Med. Oral Patol. Oral Cir. Bucal. 16(1): 62-67.

Ford, J.C., Zheng, D. \& Williamson, J.F. 2011. Estimation of CT cone-beam geometry using a novel method insensitive to phantom fabrication inaccuracy: Implications for isocenter localization accuracy. Medical Physics 38(6): 2829-2840.

Gulsahi, A. 2009. Bone quality assessment for dental implants. In Implant Dentistry - The Most Promising Discipline of Dentistry, edited by Turkyilmaz, I. Croatia: European Union: InTech.

Hsu, J.T., Chang, H.W., Huang, H.L., Yu, J.H., Li, Y.F. \& Tu, M.G. 2011. Bone density changes around teeth during orthodontic treatment. Clinical Oral Investigations 15(4): 511-519.

Isoda, K., Ayukawa, Y., Tsukiyama, Y., Sogo, M., Matsushita, Y. \& Koyano, K. 2012. Relationship between the bone density estimated by cone-beam computed tomography and the primary stability of dental implants. Clinical Oral Implants Research 23(7): 832-836.

Kaya, S., Yavuz, I., Uysal, I. \& Akkuş, Z. 2012. Measuring bone density in healing periapical lesions by using cone beam computed tomography: A clinical investigation. Journal of Endodontics 38(1): 28-31.

Schulze, R.,Heil,U., Groß, D., Bruellmann, D.D., Dranischnikow, E., Schwanecke, U. \& Schoemer, E. 2011. Artefacts in CBCT: A review. Dentomaxillofacial Radiology 40(5): 265-273.
Shapurian, T., Damoulis, P.D., Reiser, G.M., Griffin, T.J. \& Rand, W.M. 2006. Quantitative evaluation of bone density using the Hounsfield index. The International Journal of Oral \& Maxillofacial Implants 21(2): 290-297.

Sun, Y., Hou, Y., Zhao, F. \& Hu, J. 2006. A calibration method for misaligned scanner geometry in cone-beam computed tomography. NDT \& E International 39(6): 499-513.

Swennen, G.R.J. \& Schutyser, F. 2006. Three-dimensional cephalometry: Spiral multi-slice vs cone-beam computed tomography. Am. J. Orthod. Dentofacial Orthop. 130(3): 410-416.

Turkyilmaz, I. \& McGlumphy, E.A. 2008. Influence of bone density on implant stability parameters and implant success: A retrospective clinical study. BMC Oral Health 8: 32.

Yunus, B. 2011. Assessment of the increased calcification of the jaw bone with CT-Scan after dental implant placement. Imaging Science in Dentistry 41(2): 59-62.

Maya Genisa*, Zainul Ahmad Rajion, Dasmawati Mohamad \& Abdullah Pohchi

School of Dental Sciences

Universiti Sains Malaysia, Health Campus

16150 Kubang Kerian, Kelantan Darul Naim

Malaysia

Mohd Rafiq Abdul Kadir

Faculty of Biomedical Engineering \& Health Sciences

Universiti Teknologi Malaysia

81310 Skudai, Johor Darul Takzim

Malaysia

Solehuddin Shuib

School of Mechanical Engineering, Engineering Campus

Universiti Sains Malaysia

14300 Nibong Tebal, Pulau Pinang

Malaysia

*Corresponding author; email: mgenisa@gmail.com

Received: 29 September 2013

Accepted: 25 May 2015 